\title{
CREDITING PRISONERS SENTENCED BEFORE 1960 WITH PRECONVICTION INCARCERATION TIME
}

In areas of social policy covered by a statute, judicial creativity is often thought to be limited to filling interstices in the legislation. The recent case of Sobell $v$. United States, ${ }^{1}$ however, demonstrates how a series of judicial acts designed to fill in the gaps, although always in light of congressional "intent," can bury the statute involved.

Morton Sobell was convicted in 1951 of violating the Espionage Act ${ }^{2}$ and was sentenced to thirty years in prison, the statutory maximum term for the offense. The statute under which he was convicted did not provide for a minimum mandatory sentence. Prior to his conviction, he was held for seven and a half months for failure to post bail, which had been set at $\$ 100,000$. At the time of his sentencing, the statutory provision determining the date on which service of sentence began did not expressly give credit for time spent in custody prior to sentencing for inability to make bail. ${ }^{3}$ However, in 1960, Congress amended the statute involved to provide "credit toward service of . . . sentence for any days spent in custody prior to the imposition of sentence . . . for want of bail . . . where the statute requires the imposition of a minimum mandatory sentence." 4 The amendment by its terms had no retroactive effect. ${ }^{5}$

In 1968, Sobell sought to correct the thirty-year sentence by gaining credit for the time he spent in presentence custody. 'The district court denied relief. ${ }^{6}$ The Court of Appeals for the Second Circuit reversed, holding that the 1960 amendment to section 3568 required that credit

1407 F.2d 180 (2d Cir. 1969).

2 Act of June 15, 1917, ch. 30, tit. I, §2, 40 Stat. 217, 218-219, as amended, 18 U.S.C. \$794 (1964).

3 Act of June 25, 1948, ch. $645, \S 3568,62$ Stat. 838, as amended, 18 U.S.C. $\$ 3568$ (Supp. III, 1965-67). The complete text reads:

The sentence of imprisonment of any person convicted of an offense in a court of the United States shall commence to run from the date on which such person is received at the penitentiary, reformatory, or jail for service of said sentence.

4 Act of Sept. 2, 1960, Pub. L. 86-691, \$1(a), 74 Stat. 738, amending, Act of June 25,1948 , ch. $645, \S 3568,62$ Stat. 838 (codified at 18 U.S.C. $\$ 3568$ (1964)). The amendment was simply added to the existing language of $\S 3568$ in the form of a proviso. It read as follows:

Provided, That the Attorney General shall give any such person credit toward service of his sentence for any days spent in custody prior to the imposition of sentence by the sentencing court for want of bail set for the offense under which sentence was imposed where the statute requires the imposition of a minimum mandatory sentence.

$5 I d . \S 2$.

- Sobell v. United States, 293 F. Supp. 124 (S.D.N.Y. 1968). The action was brought under 28 U.S.C. $\$ 2255$ (1964), which in part provides that where the sentence was imposed "in violation of the Constitution or laws of the United States" or "was in excess of the maximum authorized by law," the defendant "may move the court which imposed the sentence to vacate, set aside or correct the sentence." 
for time spent in presentence custody for want of bail be given where the sentence was imposed before 1960 for an offense not requiring a minimum mandatory sentence. ${ }^{7}$

The Second Circuit's reasoning relied upon Stapf $v$. United States, ${ }^{8}$ which had construed the 1960 amendment to require courts to give credit for time spent in presentence custody to all prisoners sentenced between 1960 and $1966^{\circ}$ who could not possibly have received such credit at the time of sentencing. ${ }^{10}$ With a regrettable lack of explanation, the court simply asserted that the rationale of Stapf applied to prisoners sentenced before $1960,{ }^{11}$ despite the fact that the amendment did not apply retroactively. ${ }^{12}$

\section{A. Prior Interpretation of the 1960 Amendment}

As the Sobell court recognized, Stapf is the leading decision interpreting the 1960 amendment to section 3568. While several courts refused to follow its interpretation, ${ }^{13}$ many accepted it, ${ }^{14}$ and the Federal Bureau of Prisons eventually promulgated uniform regulations in accord. ${ }^{15}$ The decision itself rested on two grounds: the congressional intent in drawing up the amendment, and avoidance of an equal protection issue that would have been raised by a contrary interpretation.

In Stapf the court argued that Congress, in drafting the amendment, wished to remedy a particular evil, not create a new one. It stated that although federal courts usually gave credit for time spent in presentence custody, they did not do so where a minimum mandatory

7407 F.2d at 182. There was technically no majority opinion in Sobell. The holding given in the text is from the opinion of Judge Hays. In a concurring opinion, Judge Moore based his decision to grant presentence credit on his interpretation of the language used by the trial judge at the time of sentencing. Id. at 183-84. Judge Friendly concurred in both opinions. Id. at 185 . Since the concurring opinion of Judge Moore raises no issues of general significance, it is not discussed. In addition, the holding in Judge Hays's opinion limited credit to cases in which it was mathematically impossible that the sentencing judge had given credit. Thus, credit could be given only when the sentence imposed plus the time spent in presentence custody added up to more than the statutory maximum sentence permitted for the offense. Id. at 183 n.8.

s 367 F.2d 326 (D.C. Cir. 1966).

9 After 1966, all federal prisoners automatically received administrative credit toward service of sentence for time spent in presentence custody. 18 U.S.C. $\$ 3568$ (Supp. III, 1965-67), amending, 18 U.S.C. § 3568 (1964).

10367 F.2d at 330. Most subsequent decisions followed the policy laid down in Stapf of not giving credit for time spent in presentence custody, unless it was mathematically impossible that the sentencing court had done so. E.g., Bryans v. Blackwell, 387 F.2d 764 (5th Cir. 1967), cert. denied, 391 U.S. 907 (1968). Contra, Padgett v. United States, 387 F.2d 649 (4th Cir. 1967) (mem.).

$11407 \mathrm{~F} .2 \mathrm{~d}$ at $182-83$.

12 Act of Sept. 2, 1960, Pub. L. 86-691, §2, 74 Stat. 738.

13 Allen v. United States, 264 F. Supp. 420 (M.D. Pa. 1966) (mem.); see United States ex rel. Sacco v. Kenton, 386 F.2d 143 (2d Cir. 1967) ; Sawyer v. United States, 376 F.2d 615 (8th Cir. 1967) (per curiam).

14 Lee v. United States, 400 F.2d 185 (9th Cir. 1968); United States v. Smith, 379 F.2d 628 (7th Cir.), cert. denied, 389 U.S. 993 (1967); Dunn v. United States, 376 F.2d 191 (4th Cir. 1967); United States v. Pratt, 276 F. Supp. 80 (D.N.J. 1967). 15 Bureau of Prisons Policy Statement No. 7600.49A. 
sentence was imposed, since it was thought that they lacked the authority to sentence a person to less than the required term. ${ }^{16}$ The result was that defendants unable to make bail in such cases were incarcerated longer than defendants who could make bail. To remedy this inequality in treatment, the 1960 amendment was passed.

At the same time, however, this amendment apparently created a new inequality of treatment: prisoners convicted of an offense requiring the imposition of a minimum mandatory sentence automatically received administrative credit for time spent in presentence custody, while prisoners convicted of lesser offenses had to depend upon the discretion of the sentencing court. To avoid such an interpretation, the court argued that Congress had assumed that credit was given by the sentencing court as a matter of course where the offense did not require a minimum mandatory sentence and thus did not deal with such cases in the amendment. ${ }^{17}$ This reading of the Congressional "state of mind" at the time the amendment was drafted is quite plausible. ${ }^{18}$ But the court also argued that the 1960 amendment implicitly approved the assumed sentencing practice of federal courts and that courts were now bound to act in accord with this legislative assumption. Courts were thus statutorily obligated to give presentence credit in cases not involving a minimum mandatory sentence.

Underlying the Congressional intent argument was the issue of equal protection. ${ }^{19}$ It would be arbitrary, irrational, and therefore unconstitutional, the court argued, to give credit automatically in cases requiring a minimum mandatory sentence when it could be denied in cases involving lesser offenses. The application of such an irrational distinction would violate the constitutional standard of equal protection. Since it was possible to construe the statute to avoid this constitutional issue, the court reasoned that it ought to do so. Therefore, it had a duty to give credit for time spent in presentence custody to all prisoners sentenced between 1960 and 1966 who could not possibly have received such credit at the time of sentencing. ${ }^{20}$ Congressional intent and the

16 See 367 F.2d at 328; Williams v. United States, 335 F.2d 290 (D.C. Cir. 1964) (defendant sentenced in 1957 for an offense involving a minimum mandatory sentence denied credit for time spent in presentence custody) ; H. R. REP. No. 2058, 86th Cong., $2 d$ Sess. 2 (1960).

$17367 \mathrm{~F} .2 \mathrm{~d}$ at 328.

18 See S. REP. No. 1696, 86th Cong., $2 d$ Sess (1960) ; H.R. REP. No. 2058, supra note 16. But see Byers v. United States, 175 F.2d 654 (10th Cir. 1949), cert. denied, 340 U. S. 949 (1951). The court stated that the defendant "was not entitled, as a matter of right, to have credit for the time he was in custody prior to sentencing, for his sentence would not commence to run until it had been imposed and he was received at the place designated for the service thereof." Id. at 656.

19367 F.2d at 328-29. Since the case involved federal law, the concept of equal protection was applied through the fifth amendment. See note 35 , infra.

$20 \mathrm{Id}$. at 330 . The court stated that whenever it was mathematically possible that credit had been given for presentence custody, i.e., the sentence actually given was less than the difference between the maximum sentence and the time spent in presentence custody, it would be presumed that credit had been given. However, since Stapf had received the maximum sentence, such a presumption could not be entertained. 
fifth amendment were thus harmonized and an irrational gap in the 1960 amendment filled.

\section{B. Legislative History of the 1960 Amendment}

The bill amending section 3568 was first introduced in the Senate. The proposed amendment was much broader than the version eventually adopted and would have given "credit toward service of . . . sentence for any days spent in custody for want of bail set for the offense under which sentence was imposed." 21 Despite the broad coverage of the bill, its purpose as stated in the report was to eliminate only the disparity in treatment under statutes requiring a minimum mandatory sentence between those who could and those who could not make bail.22 The bill was not intended to deal with possible unfairness to all defendants unable to make bail.

The language of the House amendment-the version eventually adopted-focused more specifically on the disparity in cases involving a minimum mandatory sentence. It stated:

Provided, That the Attorney General shall give any such person [convicted of an offense in a court of the United States] credit toward service of his sentence for any days spent in custody prior to the imposition of sentence by the sentencing court for want of bail set for the offense under which sentence was imposed where the statute requires the imposition of a minimum mandatory sentence. ${ }^{23}$

The purpose of the House amendment remained the same as the Senate's : to eliminate the disparity in treatment under statutes requiring a minimum mandatory sentence between those who could and those who could not make bail. ${ }^{24}$ However, "[i]n order to clarify the intent, it was decided to expressly spell out in the text of the bill the fact that this provision applies where the statute requires the imposition of a minimum mandatory sentence." 25

The only recorded comment concerning the significance of the difference between the two bills by a member of Congress was made when the then Senator Johnson put the amended bill before the Senate for a vote. He stated that "the House amendment is in the nature of a substitute . . . and provides that the application of the statute is only in those cases which involve the imposition of a minimum mandatory sentence." 26

Despite Senator Johnson's remarks, it does not appear that the House amended bill resulted from a conscious intention to deny adminis-

21 S. REP. No. 1696, supra note 18, at 2.

$22 I d$.

23 H.R. REP. No. 2058, supra note 16, at 2 (emphasis added).

$24 \bar{I} d$

25 Id.

28106 CoNG. Rec. 17464 (1960) (emphasis added). 
trative credit for time spent in presentence custody to defendants convicted of an offense not requiring the imposition of a minimum mandatory sentence. The intent was rather "to clarify" the Senate bill to insure that defendants subject to a minimum mandatory sentence would receive such credit, since it was assumed that they were the only defendants denied credit as a matter of course. The amended bill was not narrower in purpose than the original version; the language of the original version was simply amended to bring it into line with its stated purpose. Nonetheless, the fact remains that the language of the House amendment limited application of the statute to cases involving a minimum mandatory sentence.

While the "evil" that Congress hoped to remedy is thus clear, much less clear is Congress's assumption about the sentencing practice of federal courts at that time. All that can be unequivocally argued is that Congress left those sentencing practices untouched. The only explicit statutory directive was that credit be given in cases involving minimum mandatory sentences and this was aimed at an administrative agency, not the courts. Section 3568 remained otherwise unaltered. ${ }^{27}$

This legislative history indicates that Congress in drawing up the 1960 amendment focused its attention on one aspect of a problem and ignored the rest of it, thereby fortuitously creating a classificatory scheme for sentencing as arbitrary and irrational as the one which preceded it. ${ }^{28}$ Faced with the task of applying this scheme in a rational manner, the court in Stapf ignored the language of the statute and looked at Congress's intent and erroneous assumptions in drawing it up. The resulting decision was more equitable than a literal application of the statute would have been.

\section{Equal Protection}

Even if one accepts the decision in Stapf, the result in Sobell does not follow inexorably. Although the court in Sobell ostensibly avoided the constitutional issue of equal protection, ${ }^{29}$ its entire argument rested on a case (Stapf) in which the equal protection issue was decisive. But that specific issue was not present in Sobell. No equal protection argument with regard to the statute could be raised for sentences imposed prior to 1960, since the amendment did not then exist and it expressly did not apply retroactively. The reasoning of the Stapf case simply does not apply to the situation which confronted the court in Sobell. The

$\mathbf{2 7}$ Notes 3 \& 4 supra.

28 The Senate report on a bill designed in part to amend $\$ 3568$ tacitly acknowledged the irrationality of the scheme created by the 1960 amendment:

It is ironic that persons accused of such serious crimes [those for which there is a minimum mandatory sentence] should be assured of receiving credit for pretrial custody, while those convicted of less serious crimes for which no minimum mandatory sentence is required have the benefit of no such assurance.

S. REP. No. 750, 89th Cong., 1st Sess. 21 (1965).

29407 F.2d at 181. 
court which sentenced Morton Sobell in 1951 did not have to concern itself with the danger of enforcing an irrational and illogical distinction, since the distinction had not yet been made. Moreover, the court in Sobell admitted the weakness of its argument when it stated that prior to 1960 , section 3568 "did not on its face require that any prisoner be given credit for presentence time spent in custody." 30

Nevertheless, the result in Sobell is still correct. Although not discussed by the court, there is a valid equal protection argument, which was raised by the appellant's counsel: ${ }^{31}$ the denial of credit for time spent in presentence custody violates equal protection by imposing on a defendant financially unable to make bail a total term of incarceration different from that imposed on a wealthier defendant.

This inequality of treatment is analogous to that condemned by a line of cases beginning with Griffin v. Illinois. ${ }^{32}$ In that case the Supreme Court held that a state statute providing full appellate review of criminal convictions only upon presentation of a transcript which must be paid for by the appellant violated the equal protection clause of the fourteenth amendment when the effect of the requirement was to deny full appellate review to the indigent. The Court held that indigent defendants must be granted the same access to review as that provided to defendants with enough money to purchase a transcript. ${ }^{33}$

The decision in Griffin indicates that if the government grants a legal right which can affect the length of imprisonment (such as the right to appellate review) in a manner which produces unequal results because of the economic status of some defendants, then the government has an affirmative duty to cure the inequality. ${ }^{34}$ Applied to the present case, ${ }^{35}$ this reasoning leads to the conclusion that the denial of presentence incarceration credit deprived Sobell of equal protection. Sobell

30 Id.; see Byers v. United States, 175 F.2d 654 (10th Cir. 1949), cert. denied, 340 U.S. 949 (1951).

31407 F.2d at 181; Brief for Appellant at 13-18, Sobell v. Unted States, 407 F.2d 180 (2d Cir. 1969).

32351 U.S. 12 (1956). See generally Comment, Equal Protection and the Indigent Defendant: Griffin and Its Progeny, 16 Stan. L. REv. 394 (1964).

33351 U.S. at 19.

34 See Note, Developments in the Law-Equal Protection, 82 HARv. L. Rev. 1065, $1177-1180$ (1969).

35 At least some of the requirements which the equal protection clause imposes on the states are applicable to the federal government via the due process clatuse of the fifth amendment. Schneider v. Rusk, 377 U.S. 163 (1964); Bolling v. Sharpe, 347 U.S. 497 (1954). The Supreme Court has explicitly refrained from holding that all the requirements of fourteenth amendment equal protection are incorporated in fifth amendment due process, limiting itself to the statement that "discrimination may be so unjustifiable as to be violative of due process." Id. at 499. In holding unconstitutional racial segregation in the public schools of the District of Columbia, the Court said in Bolling that "[c]lassifications based solely upon race must be scrutinized with particular care, since they are contrary to our traditions and hence constitutionally suspect." Id. No less can be said about classifications based on wealth affecting the length of time criminal defendants spend in prison. Bolling also states that liberty cannot, under the due process clause of the fifth amendment, "be restricted except for a proper governmental objective," $i d$. at $499-500$, reasoning which is equally applicable to cases like Sobell in which the length of imprisonment depends on wealth. For these reasons, precedents developed under the fourteenth amendment equal protection clause should be treated as fully applicable to the federal government in this area. 
was sentenced without regard to his presentence confinement, which was the result of inability to make bail. Thus, had relief been denied, he would have had to spend a longer aggregate amount of time in jail than one who could afford bail..$^{38}$ The evil in such a case is similar to that condemned in Griffin. The poorer defendant is obliged to suffer imprisonment which he would be spared were he richer. ${ }^{37}$

A possible objection to this reasoning is that time spent in prison for failure to make bail differs in purpose from time spent in prison after conviction for a crime. ${ }^{38}$ Presentence imprisonment is designed to insure the presence of the accused at trial; imprisonment after conviction is designed to serve the various different purposes of punishment. Although this distinction may be relevant in other contexts, its use here is inappropriate. It may be true that at the time bail is fixed it is not unconstitutional to treat persons accused of crimes in different ways, if the unequal treatment is necessary to insure the presence of the defendants at trial. Since the determination has been made that bail is necessary to assure the defendant's presence at trial, the inequality inherent in imprisoning the indigent for that reason is legitimate because unavoidable. However, when the defendant is sentenced the state has the opportunity to correct this unequal treatment, by reduction of the length of sentence. This reduction insures that the total length of time spent in prison for the two purposes of assurance of presence at trial and of punishment will not differ on the basis of whether the defendant is rich or poor. The failure of the state to correct the unequal treatment is a denial of the equal protection of the laws, just as the failure of Illinois to provide the indigent defendant with appellate review, when it was provided to others, was a similar denial. ${ }^{\mathbf{3 9}}$

${ }^{36}$ That Sobell was sentenced prior to the decision in Griffin raises no problem. Griffin has been held to apply retroactively. Eskridge v. Washington State Bd. of Prison Terms \& Paroles, 357 U.S. 214 (1958) (per curiam).

${ }^{37}$ In the case of defendants unable to make bail but thereafter released and acquitted, a similar inequality exists. But if setting bail is necessary to assure a defendant's appearance at trial, there is no way to serve this purpose without incarcerating the indigent defendant. His treatment, although unequal, serves a compelling governmental interest. This is not the case where conviction and imposition of sentence provides an opportunity to rectify the unequal treatment. Cir. 1969).

38 See Brief for Appellee at 10-11, Sobell v. United States, 407 F.2d 180 (2d

39 Both briefs in the Sobell case raised the possibility that Sobell's failure to post bail was due to some unspecified reason other than financial inability. Brief for Appellant at 17-18, Brief for Appellee at 10, Sobell v. United States, 407 F.2d 180 (2d Cir. 1969). Here again an ostensibly neutral sentencing rule may produce different results when applied to different defendants. Where the defendant freely chooses not to make bail, that choice, rather than the rule denying credit, is the origin of the unequal treatment, and there would be no basis for arguing a denial of equal protection. Where the reason for the failure to post bail is beyond the defendant's control, but unrelated to his economic status, the reasoning of Griffin may not be applicable, since the chief concern there was the unequal treatment accorded indigent defendants. However, it may be argued that a failure to give credit in the latter situation violates the due process clause of the fourteenth amendment. Brief for Appellant at 17-18, Sobell v. United States, 407 F.2d 180 (2d Cir. 1969). To base a determination of the total length of time spent in prison on a factor as arbitrary and varying as the length of time spent in presentence custody is arguably capricious and irrational, and thus a violation of due process. 


\section{ConCLUSION}

The court may have avoided basing its decision on such an argument because of the impact it would have had on state, as well as federal sentencing practice. Nonetheless, the unequal treatment accorded Sobell in requiring him to serve the maximum term for the offense plus the seven and a half months spent in presentence custody for inability to make bail was the issue in the case, not the interpretation of an amendment which could not possibly have applied in 1951. Had the court faced this issue, it could have written an opinion less offensive to logic and with an equally equitable result-freedom for Sobell. Instead, although the amendment is limited by its terms to requiring credit for time spent in presentence custody to prisoners sentenced after 1960 for offenses imposing a minimum mandatory sentence, it was used to give credit to a prisoner sentenced in 1951 for an offense imposing no minimum mandatory sentence. Even a repealed amendment deserves more respect than this. Hopefully, future decisions on cases like Sobell's will face the issue involved. 